\title{
Determinants of Financial Report Reliability: Internal Control System Perspective: An Empirical Study on Takalar District Government
}

\author{
Muh. Nur Fithri D., Mahfudnurnajamuddin, Baharuddin Semmaila, and Nurpadilah Nurpadilah
}

\section{ABSTRACT}

The dimensions of the Government internal control system (GICS) in relation to the Reliability of government financial statements are investigated in this study (RGFS). This research employs 3,810 civil personnel who operate in 15 (fifteen) Service Agencies in regional work units of the local government of Takalar District, South Sulawesi Province. Employees in official offices are chosen because of the variety of jobs that they perform, as well as their duties and responsibilities, and because of this diversity of work, employees are expected to have sufficient knowledge and experience in optimizing the internal control system and report reliability of the finances government. The results of a unidirectional link between Risk Assessment, Control actions, Information \& Communication, and Monitoring have a substantial effect on RGFS, according to the results of a t-statistical study utilizing regression. In the Takalar District Government, there is just one dimension in the Government internal control system (GICS) that cannot increase the Reliability of government financial statements (RGFS), namely the Control environment dimension $\left(\operatorname{GICS}_{1}\right)$.

Keywords: GICS, RGFS, Regional working unit, Takalar.
Submitted : December 26, 2021

Published : January 19, 2022

ISSN: 2507-1076

DOI: $10.24018 / \mathrm{ejbmr} .2022 .7 \cdot 1.1220$

Muh. Nur Fithri D.*

Universitas Muslim Indonesia, Indonesia. (e-mail: muhnurfithri@gmail.com)

Mahfudnurnajamuddin

Universitas Muslim Indonesia, Indonesia. Baharuddin Semmaila

Universitas Muslim Indonesia, Indonesia. Nurpadilah Nurpadilah

Universitas Muslim Indonesia, Indonesia.

*Corresponding Author

\section{INTRODUCTION}

Good governance developed exclusively to the reinstatement of an open, participatory, and accountable climate. A climate of openness produced via clear, accurate, and effective communication with stakeholders can aid in the timely and effective implementation of an activity. Openness is a fundamental principle of good governance in the public sector, and it is necessary to ensuring that governance is accessible and accountable (Rusvianto et al., 2018).

Financial statements are prepared to present pertinent information about a reporting entity's financial circumstances and all transactions made during a reporting period. Financial statements are primarily used to determine the value of economic investments made to carry out government operational activities, analyze financial condition, evaluate a reporting entity's effectiveness and efficiency, and aid in determining compliance with laws and regulations. Local government financial statements must be designed to satisfy the purpose of presenting financial statements by meeting the qualitative characteristics of financial statements as a normative measure that must be realized in government accounting information (Government Regulation of the Republic of Indonesia Number 71 of 2010).

Financial statements prepared in conformity with many of these regulations are being used to provide relevant information about a reporting entity's financial circumstances and all review defines during a reporting period. Financial statements are generally used to identify the value of economic resources consumed to carry out government operational activities, analyze financial condition, evaluate a reporting entity's efficiency and effectiveness, and aid in establishing compliance with the regulations. Local government financial reports must be created to satisfy the purpose of presenting financial statements by meeting the qualitative qualities of financial statements as a normative measure that must be realized in government accounting information (Syarifudin, 2014; Sitepu et al., 2017).

Financial reports provided by local governments (LKPD) are intended to meet the general purpose of reporting, and financial reports produced by local governments will later be used in decision-making by the parties concerned. The Supreme Audit Agency will measure the quality of LKPD each year in the form of an opinion (BPK). Implementing Government Accounting Standards can benefit from improved reports produced by local governments (SAP). Because Government Accounting Standards (SAP) are the framework for the government in preparing and presenting financial reports with both the purpose of improving the quality of all those reports.

In Indonesia, the issue of regional financial accounting systems and the credibility of the financial reports is an intriguing and significant topic to investigate, because financial statements have been used in reality. The central government and local governments in Indonesia continue to find data that is not accurately presented, and the Supreme 
Audit Agency of the Republic of Indonesia manages to find several inconsistencies in the audit of financial reports (Sahabuddin et al., 2021). The goal of all parties to create accurate financial reports necessitates the establishment of a credible accounting system even by government, both central and local. A quasi-accounting system has an impact on the application of inadequate internal controls, and the presentation of the accompanying financial statements has several problems that make these unsuitable for use as a decision-making instrument (Anna et al., 2020; Safkaur et al., 2021).

Local government financial accounting information that is presented in its whole contains all information that can affect decision-making while taking into account existing limits. As a result, financial statement dependability is a reflection of the ability of information to convey confidence that the information is correct or genuine, allowing data availability to be approximated without dramatically compromising the reliability, resulting in total benefits to all users (Hoang \& Phang, 2021; Ozili, 2021). The truth of the information is required for the accuracy of financial information presentation and the minimization of major errors (Kusuma et al., 2021; Trisnawati \& Nugraha, 2021).

In Indonesia, as revealed by the Takalar District Government, it was observed that the regional financial accounting system had not been successfully implemented in numerous cases, resulting in incorrect financial reporting. This situation occurs because the government has not prioritized and devoted close attention to the use of applicable Government Accounting Standards in preparing regional financial reports, leading to financial statements that really are useless for managing regional assets. Local governments can establish regulations or policies regarding the financial accounting system as needed, and the process of creating effective financial management is carried out with the help of the best system.

The regional financial accounting system should be established in compliance with applicable laws on internal control and government accounting standards, as well as government regulations on control environment (Wiranti \& Wahidahwati, 2021). Local governments should be able to present financial reports that are timely and compatible with Government Accounting Standards (SAP).

According to Government Regulation (PP) Number 71 of 2010, the government's financial statements will be produced, then audited by the Supreme Audit Agency (BPK), and finally submitted to the Central and Regional Houses of Representatives, as well as the general public. Budget Realization Reports, Balance Sheets, Cash Flow Statements, and Notes to Financial Statements are included within the financial statements submitted. The goal of Local Government Financial Reports (LKPD) is to fulfill the general purpose of financial reporting, and the financial reports produced by local governments will be used later in decision-making by the parties concerned. The Supreme Audit Agency will assess the quality of local government financial reports (LKPD) every year in the form of an opinion (BPK).

The quality of local government financial reports can be improved by implementing Government Accounting Standards (SAP). Because Government Accounting
Standards (SAP) are the basis for the government in compile and present financial reports that aim to improve the quality of government financial reports. Relevant, trustworthy, comparable, and easy to understand are really the essential attributes that increase the quality of financial reports. According to the findings of the Supreme Audit Agency of the Republic of Indonesia on Local Government Financial Reports (LKPD) in the Takalar District, 3 (three) reporting entities, or 8.33 percent, are still receiving a TMP opinion or disclaimer. This shows that the LKPD has always had flaws in the qualitative characteristics of financial statements and does not comply with government accounting standards (SAP).

The insufficient implementation of the Internal Control System, which had an impact on the trustworthiness of the Regional Government Financial Reports, was recognized as the cause of the non-optimal application of government accounting standards (SAP) (Amnan et al., 2019) The agency relationship, thus according agency theory, is a contract wherein the one or more entities (principals) instruct another person (agent) to perform a function on their behalf and authorizes the agent to create the correct decision for the principle.

The obligation of the trustee (agent) to give accountability, present, report, and divulge all activities and activities that are their responsibility to the trustee (principal), who has the right and authority to demand such accountability, is known as public accountability (Jensen \& Meckling, 1976). The implications of agency theory in the field of government accounting show that the government has an obligation to publish financial statements that contain transparent and accountable information for users of financial information in its position as an agent.

The government, in its capacity as principal, examines the financial statements' openness and accountability while also utilising the financial information to make economic, social, and political decisions (Mattoasi et al., 2021). Government Regulation No. 60 of 2008 concerning the Government Internal Control System (SPIP) of the Republic of Indonesia explains that an integral process of activities must be carried out continuously by the leadership of all employees to ensure adequate trust in the organization to achieve its goals through good financial reporting, safeguarding government assets, effective, and efficient, because he Compliance with the provisions of all relevant laws and regulations. An integrated set of actions and activities that provide an adequate understanding of an organization's goals through effective and efficient activities, reliable financial reporting, state economic circumstances, and compliance with laws and regulations, which are all carried out on a continuing basis by superiors and subordinates.

A previous study conducted by Wijaya \& Pratiwi (2021) showed evidence that the local government internal control system had a real impact on increasing reliability on the quality of local government financial reports. The research is relevant to the findings of Trisnawati \& Nugraha (2021); Ramadhan \& Arza (2021); Faturey et al. (2021); Fazlurahman et al. (2021); Kesuma, et al. (2018) that the government's internal control system has a positive effect on the quality of financial reports.

Some of the findings of these previous researchers received 
rebuttal from other researchers, Purbasari \& Bawono (2017) that the local government internal control system has a negative but real impact on the quality of local government financial reports. Latifah (2017) the findings of her study prove that a good internal control system in its implementation is not able to improve the quality of regional financial reports.

\section{LITERATURE REVIEW}

\section{A. The Government's Internal Control System}

Implementation of the government control environment can be realized by implementing; upholding integrity and ethical values; commitment to competence; conducive leadership; establishment of an organizational structure in accordance with the needs; proper delegation of authority and responsibility; formulation and implementation of sound policies regarding the development of human resources; embodiment of the role of an effective government internal control apparatus; and good working relationship with relevant Government Agencies.

Risk assessment is focused with the likelihood of events that could jeopardize the attainment of goals and objectives. Risks need to be identified and analyzed by agency officials. Control activities take the shape of steps taken to mitigate hazards. As a result, policies and processes must be established to ensure that risk reduction efforts are carried out effectively. Control activities include: reviewing the performance of governmental Agencies; human resource development; control over the management of information systems; physical control over assets; determination and review of performance performance measures; separation of functions; authorization of important transactions and events; accurate and timely recording of transactions and events; restrictions on access to resources and their records; accountability for unpermitted access to resources and their records.

In order to realize the elements of the government's internal control unit, the head of the agency is obliged to identify, record, and communicate information in the right form and time. Communication must be effective because it is necessary to provide and utilize various forms and means of communication. Information systems are managed and developed and updated on an ongoing basis. Monitoring of the quality of the performance of the Internal Control Unit is carried out by the head of the agency through continuous monitoring, separate evaluation and follow-up on audit results and reviews.

According to Government Regulation Number 71 of 2010 of the Republic of Indonesia, the quality attributes of a government financial report are a normative prerequisite that must be done in order for government financial reports to provide the desired quality, namely relevant, reliable, comparable, and understandable. In order to ensure excellent financial management, the process of managing regional funds in an agency must be organized as much as practicable.

The normative characteristics needed so that government financial statements can meet the desired quality are described in Government Accounting Standards (SAP) in the Government Accounting Conceptual Framework (KKAP) section explaining the measuring constructs of financial statements, namely: relevant, reliable, comparable, and understandable. Financial statements are said to be relevant if the information contained in them can influence users' decisions by helping them evaluate past or present events, and predict the future, as well as confirming or correcting the results of their evaluations in the past. In order for this relevance to be achieved, the financial statements must be presented on time.

If the information in financial information is free in misleading understanding and substantial errors, presents relevant circumstances honestly, and can be checked, it is calmly and rationally. Whereas information may be relevant, its utilization can be misleading if the nature or presentation of the information is inaccurate. As a consequence, financial reports from local governments must be provided in a way that protects its accuracy and consistency. This is done in order to achieve accountability and transparency in local government implementation (KKAP paragraph 22). The ability of information to generate confidence that the information is truthful or valid is defined as financial statement reliability. Financial statement information must be credible, that is, free of misunderstandings and major errors, disclose all facts correctly, and be traceable (Kesuma et al., 2018).

\section{B. Reliability of Financial Statements}

Thus, according to Government Regulation Number 71 of 2010 , financial reporting reliability is defined as information in financial statements that is free of misleading understanding and material errors, presents all facts honestly, and can be verified, and where reliable information fulfills the attributes of honest, verifiable, and neutral presentation. The demonstration of balance sheets, revenue and expenditure reports, and notes to financial statements is typically associated with the presentation of any factual information and verifiable financial statements for general needs that are presented fairly and honestly, and the material provided can be evaluated and reconciled periodically between accounting records and bank records (Muda et al., 2018). Reliability (timeliness). Financial statement punctuality includes the provision of information for decision makers when they need something before it loses its potential to inspire (Government Regulation Number 71 of 2010).

Early information submission can be utilised as a platform for making economic options and preventing delays in making these decisions can be interpreted as timely (Naviantia, 2020). The Internal Control System is an integral process of actions and activities carried out continuously by the leadership and all employees to provide adequate assurance on the achievement of organizational goals through proper and effective activities, accurate accounting reporting, safeguarding state assets, and compliance with legislation, as according to Government Regulation Number 60 of 2008.

Internal control, according to Muda et al. (2018), comprises the synchronization of organizational structure, procedures, and mechanisms in order to maintain organizational wealth, ensure the authenticity and reliability of accounting data, increase efficiencies, and adhere to leadership policies. Financial oversight is required. Financial supervision is also aimed at gaining sufficient confidence in 
the organization's efficacy and efficiency, the accuracy of financial reporting, and compliance with rules (Kiswanto et al., 2020). Regional government supervision, according to Article 16 of the President of the Republic of Indonesia's Decree No. 74 of 2001 concerning Practices for Mentorship of the Application of Local Authority, is a process of activities aimed at ensuring that regional governments continue operating in accordance with the plans and provisions of the legislation and regulations

\section{Conceptual Framework}

The relationship between the dimensions contained in the government's internal control system as elements affecting the financial statement's reliability is examined in this study. Thus according signal theory, the Government's Internal Control System (SPIP), which includes the control environment, risk assessment, control activities, information and communication, and internal control monitoring, is an activity that cannot stand alone and therefore must be carried out continuously by all components involved in order to increase the agency's and principal's trust, and also the trust of all stakeholders, so that the integration results in reliable financial reporting and meets all specifications. The statement explains how the more successfully the government's internal control system is introduced, the much more trustworthy government financial statements emerge.

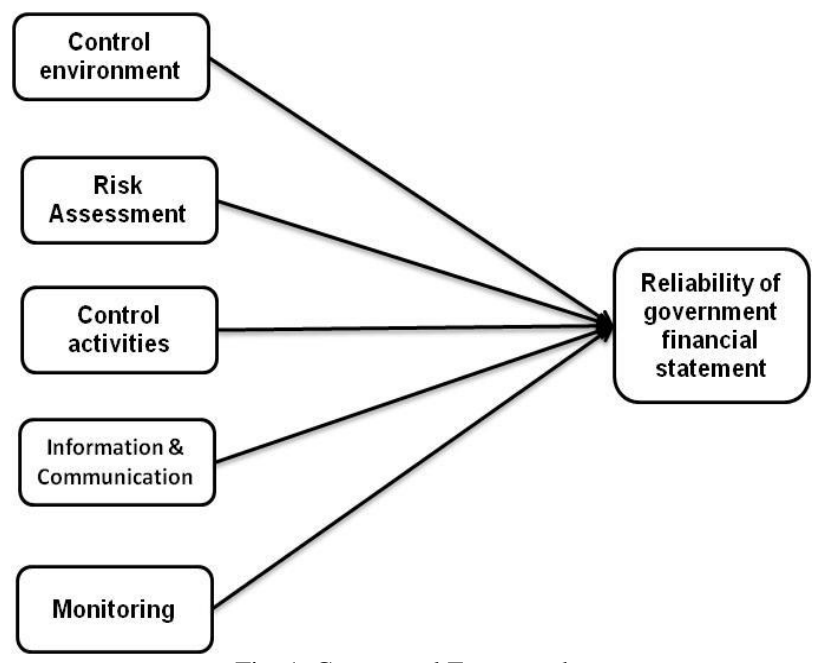

Fig. 1. Conceptual Framework.

\section{RESEARCH METHODS}

This research is an approach that attempts to re-examine the relationship among the variables and then test hypotheses; as a result, the methodology used in this research is a quantitative approach, which is a method of gathering information using research instruments and statistical analysis with the objective of testing hypotheses and relationships variables.

The study was conducted out in Takalar District, South Sulawesi Province, with the assistance of the Regional Work Unit (SKPD), which would be part of the Takalar District local government. The population of this research exclusively uses 3,810 state civil servants who work in 15 (fifteen) Service Agencies in the regional work unit, which is in the form of an official organization. Employees are expected to have sufficient knowledge and experience in optimizing the internal control system and the reliability of government financial reports even before working in an official office due to the variety of jobs that are the roles and responsibilities of employees. With the diversity of work, employees are expected to have knowledge and experience in optimizing the internal control system and the reliability of government financial reports. The sample is determined using the Slovin formula with a precision of 5\%, yielding a sample of 146 employees as respondents, who are expected to provide perceptions based on their responsibilities and duties in carrying out their work on the government's internal control system, and also the importance of financial reporting as part of their work so far in this.

\section{RESUlTS}

Ages, marital status, and work experiences all play a role in how participants characterize these findings.

TABLE I: RESPONDENTS

\begin{tabular}{ccc}
\hline \hline Criteria & $\begin{array}{c}\text { Participants' } \\
(\mathrm{N}=146)\end{array}$ & Percentage $(\%)$ \\
\hline Ages (Years) & & \\
\hline$<30$ & 32 & 21,9 \\
$30-39$ & 38 & 26,0 \\
$40-49$ & 47 & 32,2 \\
$>50$ & 29 & 19,9 \\
\hline Marital Status & & \\
\hline Married & 117 & 80,1 \\
Singles & 29 & 19,9 \\
\hline Work experiences (Years) & & \\
\hline$<5$ & 19 & 34,0 \\
$6-10$ & 50 & 36,3 \\
$11-15$ & 53 & 16,4 \\
$>16$ & 24 & \\
\hline \hline
\end{tabular}

The features of the respondents are presented at the outset in order to establish the psychological state of the apparatus in relation to the completion of their work. There were 146 respondents who responded to statements that were dominated by the age of 40-49 years, with a total acquisition of 47 state civil workers (32.2 percent), with 117 married officers (80.1 percent), and with dominant work experience. for 11-15 years (36.3 percent).

These individual characteristics suggest that the apparatus has a high level of expertise and knowledge, as well as a high level of work desire to work diligently in line with their roles and obligations, implying that they are capable of producing high-reliability financial reports.

The instrument's validity and reliability are checked in the second stage, with a correlation coefficient and Cronbach alpha $>0.60$,

Based on the data below, it can be concluded that the entire construct has a Mean > Standard Deviation value, stating that the data on the construct is likely to be used suitably, and the validity and reliability experimental investigations are declared valid based on the total Pearson correlation value of 0.77 in the Control environment (Cronbach 0.84), 0.78 in the Risk Assessment surroundings (Cronbach 0.82), 0.92 in the Control Activities environment (Cronbach 0.91), and 0.94 in the Information environment. The use of regression in an analytical model is conditionally in the next section whether the data has met the requirements of the assumptions that can be verified. 
TABLE II: DESCRIPTIVE STATISTICS, VALIDITY AND RELIABILITY

\begin{tabular}{ccccc}
\hline Construct & Mean & SD & $\begin{array}{c}\text { Pearson } \\
\text { Correlation } \\
>0,60\end{array}$ & $\begin{array}{c}\text { Cronbach } \\
\text { Alpha } \\
>0,60\end{array}$ \\
\hline $\begin{array}{c}\text { Control } \\
\text { environment }\end{array}$ & 4,13 & 0,79 & 0,77 & 0,84 \\
Risk Assessment & 4,15 & 0,77 & 0,78 & 0,82 \\
$\begin{array}{c}\text { Control activities } \\
\text { Information \& }\end{array}$ & 3,97 & 0,75 & 0,92 & 0,91 \\
$\begin{array}{c}\text { Communication } \\
\text { Monitoring }\end{array}$ & 4,13 & 0,80 & 0,94 & 0,85 \\
$\begin{array}{c}\text { Reliability of } \\
\text { government }\end{array}$ & 4,24 & 0,77 & 0,87 & 0,93 \\
financial statement & 4,17 & 0,80 & 0,91 & 0,90 \\
\hline \hline
\end{tabular}

\begin{tabular}{lcc}
\multicolumn{3}{c}{ TABLE III: NORMALITY } \\
\hline \hline \multicolumn{1}{c}{ Model test } & Z-score & p-value \\
\hline Runs Test & -1.687 & 0,077 \\
One-Sample KS Test & 0.060 & 0,2 \\
\hline \hline
\end{tabular}

The first assumption test confirms that "normality tests employed show that the data has true normality if the p-value is greater than 0.05 . Autocorrelation analysis is performed in the second step of assumption testing, as outlined in table below:

TABLE IV: AUTOCORRELATION

\begin{tabular}{cc}
\hline \hline Parameters & Results \\
\hline DW & 2.079 \\
DU & 1.7861 \\
DL & 1.6736 \\
\hline \hline
\end{tabular}

The Durbin Watson test is 2.079 at alpha level $=0.05$, with a sample of $146(n) d n(k=5)$ for the independent variable, the DL value is 1.78610 and the DU value is 1.67368 , meaning $2.079>1.786>1.673$, so it can be concluded that the model has no autocorrelation.

TABLE V: MULTICOLLINEARITY

\begin{tabular}{ccc}
\hline \hline Constructs & Toll. & VIF \\
\hline GICS $_{1}$ & 0.836 & 1.196 \\
GICS $_{2}$ & 0.876 & 1.141 \\
GICS $_{3}$ & 0.823 & 1.215 \\
GICS $_{4}$ & 0.891 & 1.122 \\
GICS $_{5}$ & 0.901 & 1.110 \\
\hline \hline
\end{tabular}

GICS with dimensions on Control Environment (GICS1), Risk Assessment (GICS2), Control Activities (GICS3), Information \& Communication (GICS4), Monitoring (GICS5), each showing the value of Collinearity Statistics for Tolerance $<1$ and the Value influence factor $<10$ so that the construct is free of multicollinearity interference.

TABLE VI: HETEROSCEDASTICITY

\begin{tabular}{cclc}
\hline \hline \multicolumn{3}{c}{ Causality (Glejser) } & P-value >0,05 \\
\hline GICS $_{1}$ & $\rightarrow$ & RGFS & 0.715 \\
GICS $_{2}$ & $\rightarrow$ & RGFS & 0.144 \\
GICS $_{3}$ & $\rightarrow$ & RGFS & 0.268 \\
GICS $_{4}$ & $\rightarrow$ & RGFS & 0.349 \\
GICS $_{5}$ & $\rightarrow$ & RGFS & 0.218 \\
\hline \hline
\end{tabular}

The results of the uniformity constantly emerging a p-value of $0.065>0.05$, while the $\mathrm{p}$-value obtained in the second test is $0.744>0.05$. Both variables have data uniformity and are clear of heteroscedasticity, based on their data. Its use of perception in certain cases requires conformance testing directions (linearity), as shown in the table below.

\begin{tabular}{|c|c|c|c|c|}
\hline \multicolumn{3}{|c|}{ Causality } & \multirow{2}{*}{$\begin{array}{c}\text { Linearity } \\
0.893\end{array}$} & \multirow{2}{*}{$\begin{array}{c}\begin{array}{c}\text { Deviation from } \\
\text { Linearity }\end{array} \\
0.104\end{array}$} \\
\hline $\mathrm{GICS}_{1}$ & $\rightarrow$ & RGFS & & \\
\hline $\mathrm{GICS}_{2}$ & $\rightarrow$ & RGFS & 0.241 & 0.121 \\
\hline $\mathrm{GICS}_{3}$ & $\rightarrow$ & RGFS & 0.061 & 0.247 \\
\hline $\mathrm{GICS}_{4}$ & $\rightarrow$ & RGFS & 0.114 & 0.179 \\
\hline $\mathrm{GICS}_{5}$ & $\rightarrow$ & RGFS & 0.811 & 0.298 \\
\hline
\end{tabular}

The table shows that the overall dimensions of the Government internal control system (GICS) Causality in the Reliability of Government Financial Statements have a linear connection (RGFS).

TABLE VIII: GOODNESS OF FIT

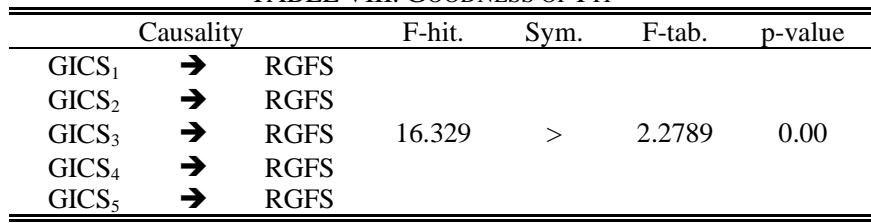

The results of the Fisher test test show that F-stat. $=16,329$ and F-tab. $=2.2789$, demonstrating that F-stat. > F-tab., clearly indicates that the regression model in this study is practicable (goodness of fit).

TABLE IX: COEFFICIENT OF DETERMINATION $\left(\mathrm{R}^{2}\right)$

\begin{tabular}{lllcccc}
\hline \hline \multicolumn{2}{c}{ Causality } & $\begin{array}{c}\text { Pearson } \\
\text { Correlation }\end{array}$ & $*$ & $\begin{array}{c}\text { Stand. } \\
\text { Coef. }\end{array}$ & Contributions \\
\hline GICS $_{1}$ & $\rightarrow$ & RGFS & 0,011 & $*$ & 0,078 & 0,001 \\
GICS $_{2}$ & $\rightarrow$ & RGFS & 0,166 & $*$ & 0,175 & 0,029 \\
GICS $_{3}$ & $\rightarrow$ & RGFS & 0,261 & $*$ & 0,216 & 0,056 \\
GICS $_{4}$ & $\rightarrow$ & RGFS & 0,201 & $*$ & 0,264 & 0,053 \\
GICS $_{5}$ & $\rightarrow$ & RGFS & 0,467 & $*$ & 0,491 & 0,229 \\
R-Square & & & & & 0,368 \\
\hline \hline
\end{tabular}

The far more major result on regression programming is GICS $_{5} \rightarrow$ RGFS, which can make a modeling contribution of 0.229 or 22.9 percentage; on the other hand, the smallest effect of its contribution is GICS $_{1} \rightarrow$ RGFS, which produces only 0.001 or 0.1 percent. Overall, the $\mathrm{R}^{2}$ for this model is 0.368 , or $36.8 \%$, indicating that the connection between the independent factors and the dependent variable is fairly strong. The following table explains how regression analysis testing on the t-test is used to verify the acceptance or rejection of the suggested hypothesis:

TABLE X: MULTIPLE REGRESSION

\begin{tabular}{|c|c|c|c|c|c|c|c|}
\hline & Causality & & $\begin{array}{c}\text { Un \& Std. } \\
\text { Coef. } \\
\text { (Beta) } \\
\end{array}$ & t-test & Sym. & t-tab. & $\begin{array}{c}\mathrm{P}- \\
\text { value }\end{array}$ \\
\hline & (Constant) & & 0,826 & & & & \\
\hline & Std. Error & & 0,274 & 3,020 & $<$ & 1,96 & 0,003 \\
\hline $\mathrm{GICS}_{1}$ & $\rightarrow$ & RGFS & 0,078 & 1,058 & $<$ & 1,96 & 0,292 \\
\hline $\mathrm{GICS}_{2}$ & $\rightarrow$ & RGFS & 0,175 & 2,435 & $>$ & 1,96 & 0,016 \\
\hline $\mathrm{GICS}_{3}$ & $\rightarrow$ & RGFS & 0,216 & 2,916 & $>$ & 1,96 & 0,004 \\
\hline $\mathrm{GICS}_{4}$ & $\rightarrow$ & RGFS & 0,264 & 3,717 & $>$ & 1,96 & 0 \\
\hline $\mathrm{GICS}_{5}$ & $\rightarrow$ & RGFS & 0,491 & 6,935 & $>$ & 1,96 & 0 \\
\hline
\end{tabular}

The table is used as the basis for the regression equation in this research, namely:

$$
\mathrm{RGFS}=\begin{aligned}
& 0,826(\alpha)+0,078\left(\mathrm{GICS}_{1}\right)+0,175\left(\mathrm{GICS}_{2}\right) \\
& +0,216\left(\mathrm{GICS}_{3}\right)+0,264\left(\mathrm{GICS}_{4}\right)+0,491 \\
& \left(\mathrm{GICS}_{5}\right)+0.274(\mathrm{e})
\end{aligned}
$$


Furthermore, which is shown in Table $\mathrm{X}$, the effect of GICS $1 \rightarrow$ RGFS value does have a t-stat. $1.058<1.96$ t-tab., implying that $(\mathrm{H} 1)$ first proposed the hypothesis that Control environment (GICS1) has an important effect on the Reliability of government financial statements (RGFS) on Local Government Takalar be denied or not substantiated. The second hypothesis (H2) presented for the consequence of GICS2 $\rightarrow$ RGFS t-value stat. 2,435>1.96 t-tab is that the Risk Assessment has a profound impact on the RGFS, which has also been demonstrated or supported. The influence of GICS3 $\rightarrow$ RGFS on t-values stat. 2,916>1.96 t-tab, and as such the third hypothesis (H3) presented is that Control activities have a significant effect on RGFS, that has been verified or supported. On the other hand, considering GICS4 has a significant effect on RGFS (t-value stat. 3.717> $1.96 \mathrm{t}$ tab), the fourth hypothesis (H4) suggested, namely Information \& Communication has a significant effect on RGFS, is supported. Finally, the final hypothesis, the effects of GICS5 $\rightarrow$ RGFS on t-values stat. 6,935 > $1.96 \mathrm{t}$-tab, is declared confirmed, demonstrating that Monitoring has a significant impact on RGFS.

The findings from this study indicate that accounting internal control in practice consisted entirely of an organizational structure, methods, and initiatives that are coordinated to maintain local government wealth, confirm accounting data accuracy and reliability, improve productivity, and comply to leadership policies (Afiah \& Azwari, 2015). Internal control is a continual process of actions and activities carried out by the leadership and all personnel to ensure that organization complies with reasonable confidence. Weak internal control makes it difficult to detect fraud or irregularities in the accounting process, leaving audit evidence based on the financial data ineffective (Monteiro et al., 2021).

Internal control refers to the structure, procedures, and measures used to maintain corporate wealth, ensure the correctness and reliability of accounting data, increase efficiency, and comply to leadership policies. Internal accounting control and internal administration are the two examples of internal control.

Internal control encompasses the entire process of auditing, reviewing, evaluating, monitoring, and other supervisory activities associated with the implementation of organizational tasks and functions in order to provide adequate assurance that activities have been carried out effectively and efficiently in accordance with established benchmarks for the benefit of the leadership in obtaining quality governance. Accounting systems and procedures, authorizations, forms, papers, and records, and segregation of roles are all significant components of accounting internal control, according to Sumaryati et al. (2020). Internal accounting control is critical for ensuring that accounting data is accurate and reliable.

Internal control, whether good or high, has an impact on the reliability of financial statements that are improving or improving, and vice versa, if bad or low internal control undermines the reliability of financial reporting. Internal control is very important in a strong accounting system. This internal control is claimed to be able to prevent accounting errors as well as provide defense for organizational data from system sabotage. Internal control is set up in this way that financial reporting adheres to the rule of law. The accounting internal control system is applied well at the Takalar District Government, according to this report's results.

Internal controls, such as matching financial statements at the beginning of the month, have proven to be effective in discovering problems and implementing corrective action on local government financial reports. The findings of Wijaya \& Pratiwi's study (2021) reveal that the internal control system of municipal governments has a real impact on improving the dependability and quality of local government financial statements. The findings of Trisnawati \& Nugraha (2021); Ramadhan \& Arza (2021); Faturey et al., (2021); Fazlurahman et al., (2021); Kesuma et al., (2018) that the government's internal control system has a beneficial effect on the quality of financial reports are applicable to this research.

These investigations yielded various findings. Some of the conclusions of past researchers differ from those of other researchers. For example, Latifah (2017) found that a good internal control system implemented correctly does not increase the quality of regional financial reports. According Purbasari \& Bawono (2017), the internal control mechanism of local governments has a negative but real impact on the quality of local government financial reports.

\section{CONCLUSION}

The data above show that there is a yet another relationship between risk assessment, control activities, information and communication, and monitoring, and that this relationship has a major impact on RGFS. In the Takalar District Government, there is just one dimension in the Government internal control system (GICS) that cannot enhance the Accuracy of government financial statements (RGFS), namely the Control environment dimension (GICS1). The theoretical implication of this study is that agency theory can explain the relationship between goals and individual behavior in terms of the Takalar District Government's financial statements' reliability. Individuals who understand why they whatever it is they're doing will have an effect on the overall performance.

The research model applied in this study kind of, such as the level of predictive power of the regression model being characterized as not good (strong enough), implying that there are other factors that can influence the reliability of financial reporting. Moreover, due to the general limited number of respondents and the use of the field survey through questionnaires, the features and opinions of respondents are not apparent in real terms. It is recommended that even more research being conducted into in the antecedents of financial reporting reliability. It may also be proposed that, in order to generalize the research findings, the dependability of financial reporting be used as an intervening variable in analyzing good corporate governance and/or extending the research area.

\section{REFERENCES}

Afiah, N. N., \& Azwari, P. C. (2015). The effect of the implementation of the government internal control system (GICS) on the quality of financial reporting of the local government and its impact on the principles of good governance: A research in district, city, and 
provincial government in South Sumatra. Procedia-Social and Behavioral Sciences, 211, 811-818.

Amnan, A. R., \& Sjahruddin, H. (2019). Pengaruh Alokasi Dana Desa dan Pendapatan Asli Desa Terhadap Belanja Desa. Jurnal Organisasi Dan Manajemen, 1(8).37-46.

Anna, N., Ridjal, S., \& Sjahruddin, H. (2020). Implementasi Financial Projection Sebagai Strategi Pengelolaan Keuangan. Jurnal Ekonomi dan Bisnis Dharma Andalas, 22(2), 302-314.

Bastian, Indra. (2003). Public Sector Accounting in Indonesia, Center. Accounting Development. Yogyakarta: Gajah Mada University

Faturey, S., Ahuluheluw, N., \& Basuki, F. H. (2021). The Influence of the Implementation of Government Accounting Standards, Internal Control Systems, Quality of Human Resources on the Quality of Local Government Financial Reports. In Conference on Economics and Business Innovation. 1(1), 368-379.

Fazlurahman, F., Afiah, N. N., \& Yudianto, I. (2021). The Effect of Utilization of Information Technology and Government Internal Control Systems on the Quality of Local Government Financial Reports with Fixed Assets Administration as an Intervening Variable (Study on BPKA Bandung City). Krisna: Collection of Accounting Research, 12(2), 250-265.

Hoang, H., \& Phang, S. Y. (2021). How does combined assurance affect the reliability of integrated reports and investors' judgments? European Accounting Review, 30(1), 175-195.

Jensen, M. C., \& Meckling, W. H. (1976). Theory of the firm: Managerial behavior, agency costs and ownership structure. Journal of financial economics, 3(4), 305-360.

Kesuma, D. P., Anwar, C., \& Darmansyah, D. (2018). The Influence of Good Governance, Implementation of Government Accounting Standards, Government Internal Control Systems and Competence of Government Apparatuses on the Quality of Government Financial Reports in the Ministry of Tourism Work Unit. E-Journal Widya Ekonomika, 1(2), 141-146.

Kiswanto, F. E., Hajawiyah, A., \& Mahera, Y. L. (2020). Factors Influencing the Weaknesses of Internal Control of Local Governments in Indonesia. Humanities \& Social Sciences Reviews, 8(1), 122-129.

Kusuma, I. L., Dewi, M. W., \& Tho'in, M. (2021). Analysis of the Effect of Human Resources Competency, Utilization of Technological Information, and Internal Control Systems on the Value of Financial Reporting Information. Annals of the Romanian Society for Cell Biology, 14628-14638.

Latifah, A. (2017). The Influence of the Implementation of Government Accounting Standards, Regional Financial Accounting Systems, Human Resource Competence and Internal Control Systems on the Quality of Regional Financial Report Information (Case Study on SKPD Bantul Regency). Accounting Study Program.

Mattoasi, M., Musue, D. P., \& Rauf, Y. (2021). The Influence of the Government's Internal Control System on the Performance of Local Governments. Jambura Accounting Review, 2(2), 100-109.

Monteiro, A. P., Vale, J., Silva, A., \& Pereira, C. (2021). Impact of the internal control and accounting systems on the financial information usefulness: the role of the financial information quality. Academy of Strategic Management Journal, 20, 1-13.

Muda, I., Harahap, A. H., Ginting, S., Maksum, A., \& Abubakar, E. (2018). Factors of quality of financial report of local government in Indonesia. In IOP Conference Series: Earth and Environmental Science (Vol. 126, No. 1, p. 012067). IOP Publishing.

Naviantia, I. A. (2020). Audit Opinion on Government Financial Report: Evidence from Local Governments in Indonesia. International Journal of Economics \& Management, 14(1).

Ozili, P. K. (2021). Accounting and financial reporting during a pandemic. In New Challenges for Future Sustainability and Wellbeing. Emerald Publishing Limited.

Purbasari, H., \& Bawono, A. D. B. (2017). The Influence of Fiscal Decentralization, Internal Control Systems and Local Government Performance on Financial Report Accountability. Indonesian Accounting and Finance Research, 2(2), 102-108.

Ramadhan, W., \& Arza, F. I. (2021). Influence of Competence, Internal Control System, Role of Village Apparatus, and Quality of Financial Report Presentation on Village Government Accountability in Managing Village Fund Allocation. Exploratory Journal of Accounting (JEA), 3(4), 822-835.

Republic of Indonesia. (2008), Government Regulation of the Republic of Indonesia Number 60 of 2008 concerning the Government Internal Control System (SPIP)

Republic of Indonesia. (2010), Government Regulation Number 71 of 2010 concerning Government Accounting Standards.

Rusvianto, D., Mulyani, S., \& Yuliafitri, I. (2018). The Influence of the Implementation of the Government's Internal Control System and
Human Resource Competence on the Quality of Local Government Financial Reports (Empirical Study on SKPD Bandung City). Banque Syar'i: Scientific Journal of Islamic Banking, 4(1), 33-67.

Safkaur, O., Yanti, D., Fery, I., \& Azwardi, PC (2021). The Role of Accounting Information System Application in Reliability Financial Reporting. Ilomata International Journal of Tax and Accounting, 2(1), 97-112.

Sahabuddin, S., Sutrisno, T., Subekti, I., \& Andayani, W. (2021). The effect of public governance, human resource quality, characteristics of the government internal supervisory apparatus, and the government internal supervisory system on the quality of local government financial reports. Accounting, 7(7), 1535-1546.

Sitepu, N. A., Sjahruddin, H., \& Idris, M. H. (2017). Pengaruh Kompetensi Aparatur Teknik Akuntansi Terhadap Kualitas Laporan Keuangan (Studi Pada Badan Pengelolah Keuangan dan Aset Pemerintah Kota Makassar). E-Library STIE YPBUP Bongaya.1-11

Sugiyono, (2013). Quantitative, Qualitative and R\&D Research Methodology. Bandung: Alphabeta.

Sumaryati, A., Praptika Novitasari, E., \& Machmuddah, Z. (2020). Accounting Information System, Internal Control System, Human Resource Competency and Quality of Local Government Financial Statements in Indonesia. The Journal of Asian Finance, Economics, and Business, 7(10), 795-802.

Syarifudin, A. (2014). The influence of HR competence and the role of internal audit on the quality of local government financial reports with the intervening variable of the government's internal control system (empirical study on the Kebumen Regency Government). Business Focus: Media for Management and Accounting Studies, 13(2).

Trisnawati, NA, \& Nugraha, AA (2021). The Influence of Human Resource Competence and Government Internal Control System on the Quality of Financial Reports. Indonesian Accounting Research Journal, 1(3), 504-516.

Wijaya, I. \& Pratiwi, N. (2021). The effect of the application of government accounting standards, human resource competence, utilization of information technology, and government internal control systems on the quality of financial reports. Hita Accounting and Finance, 2(4), 75-84.

Wiranti, WP, \& Wahidahwati, W. (2021). The Influence of Financial Accounting Systems, Information Technology and Internal Control Systems on the Quality of OPD Financial Reports. Journal of Accounting Science and Research (JIRA), 10(5). 